\title{
Citizenship Information Service Provision in the United Kingdom: a study of 27 case agencies
}

\section{Rita Marcella and Graeme Baxter}

\section{Biographical notes}

Rita Marcella is Reader/Senior Lecturer at the School of Information and Media, the Robert Gordon University, Aberdeen. She has been Course Leader for the Msc in Information Analysis since its inception. Research interests include citizenship information, European information, gender and communication, business information and help desk development. She has also published textbooks on classification and biography for children.

Graeme Baxter is a Research Assistant at the School of Information and Media, the Robert Gordon University. A former student of the School, his research interests include citizenship information and European information.

\section{Contact details}

School of Information and Media Robert Gordon University

Garthdee Road

Aberdeen

AB10 7QE

United Kingdom

Tel: (01224) 263904

Fax: (01224) 263939

E-mail: r.marcella@rgu.ac.uk

Abstract: This paper presents the results of 27 case study visits to public libraries, Citizens Advice Bureaux and other advice agencies throughout the UK. The main aim of the visits was to examine existing levels of citizenship information provision within these organisations. The visits consisted of interviews with staff and examination of the organisations' collections of citizenship/community information. 
The case studies gathered data on: the extent to which these organisations provide citizenship information and/or advice; staff and training issues; the types of citizenship enquiries most frequently received; local demographic factors that affect citizenship information need; the type and arrangement of materials used to answer enquiries; the public's preferred methods of approaching the organisations; user satisfaction with services; the use of information and communication technologies to aid citizenship information provision; links with other citizenship information providers; and future plans to develop services.

The findings suggest that, in terms of citizenship information provision, public libraries can learn from Citizens Advice Bureaux and vice versa. The paper concludes by suggesting that public libraries could develop a more proactive approach to the identification of issues where information is being or will be required by users.

\section{Background and methodology}

This paper reports the results of a series of case study visits to public library authorities, Citizens Advice Bureaux (CABx) and other generalist information and advice agencies throughout the UK, conducted as part of a research project, funded by the British Library Research and Innovation Centre, investigating the citizenship information needs of the UK public. The authors have developed the following definition of citizenship information:

Citizenship information is information produced by or about national and local government, government departments and public sector organisations which may be of value to the citizen either as part of everyday life or in the participation by the citizen in government and policy formulation.

The main aims of this project were: to investigate the extent to which members of the public in the UK have expressed or unexpressed needs for citizenship information; to explore their preferred routes to the acquisition of such information; and to investigate both the suitability and approachability of the public library, among other agencies, for the user seeking citizenship information. The more specific aims of the case study visits were to examine existing levels of provision of citizenship information throughout the UK, and to gather information on, for example, the ways in which the public approach information providers to 
obtain citizenship information, the types of enquiries most frequently received, and the sources used to answer these enquiries.

A total of 27 visits were made, covering all 13 Government Office Regions of the UK. In general, one library authority, plus either one $\mathrm{CAB}$ or other advice agency, was visited in each region. These organisations were identified using the directory Libraries in the United Kingdom and the Republic of Ireland (Library Association, 1996), the CAB service directory (National Association of Citizens Advice Bureaux, 1996a), Citizens Advice Scotland's Directory of information (1996a), and, for the other advice agencies, the appropriate Yellow Pages for the regions concerned, together with Internet searches. On the whole, organisations were eager to participate in the project. Indeed, only three refusals were received (a lack of staff time being cited in each case), and alternative participants were readily obtained.

The visits consisted of face-to-face interviews with representatives of the organisations, together with a tour and close examination of the relevant sections of their collections. As the authors' definition of citizenship information has a close affinity with many commentators' definitions of community information (see, for example, Donohue (1976) and the Library Association (1980)), the public library interviews were conducted with members of staff closely involved in community information matters. In the $\mathrm{CABx}$ and other advice agencies, meanwhile, interviews were conducted with either the manager or deputy manager. In total, 28 interviews involving 34 individuals were conducted, each interview following a semi-structured schedule and lasting, on average, 45 minutes. All interviewees were responsive and very interested in the project. The vast majority of the interviews took place between August and October 1997, the remainder being conducted in October and November 1998. All interviews were recorded on audio tape for subsequent transcription and analysis.

In addition to these case study visits, all of the organisations assisted in the research by distributing questionnaires on citizenship information need to their users/clients; the results of that survey have been discussed elsewhere by the authors (Marcella and Baxter, 1999). 


\section{Background to organisations visited}

\section{Public Libraries}

In its 1993 Charter for Public Libraries, the Library Association stated that the role of the UK public library network is to "give everyone access to books, information and works of creative imagination which will:

- encourage them to take part in cultural, democratic and economic activities;

- educate them, either formally or informally;

- help them make good use of their free time;

- promote reading as a basic skill for life; and

- make them aware of the value of information and encourage them to use it."

Thirteen public library authorities were visited during this stage of the research. These are listed in Table 1, together with statistics obtained from the Chartered Institute of Public Finance and Accountancy public library statistics 1996-97 actuals (CIPFA, 1998).

\begin{tabular}{|l|c|c|c|c|c|c|}
\hline \multicolumn{2}{|l|}{ Table 1: Case study library authority statistics 1996-97 } \\
\hline $\begin{array}{l}\text { Library } \\
\text { Authority }\end{array}$ & $\begin{array}{c}\text { Resident } \\
\text { population }\end{array}$ & $\begin{array}{c}\text { Area } \\
\text { (Hectares) }\end{array}$ & $\begin{array}{c}\text { Service } \\
\text { points }\end{array}$ & $\begin{array}{c}\text { Staff estab } \\
\text { (FTE) }\end{array}$ & Enquiries & Visits \\
\hline Aberdeenshire $^{1}$ & 226,060 & 629,047 & 42 & 97.1 & - & - \\
\hline Belfast & 297,300 & 13,979 & 23 & 200.0 & 756,251 & $1,782,049$ \\
\hline Birmingham & $1,020,600$ & 26,785 & 44 & 582.8 & $1,668,836$ & $6,227,624$ \\
\hline Brighton \& Hove $^{2}$ & - & - & - & - & - & - \\
\hline Cambs & 703,300 & 339,963 & 59 & 248.9 & 946,385 & $4,429,191$ \\
\hline Camden & 189,100 & 2,172 & 14 & 164.0 & 421,093 & $1,326,171$ \\
\hline Ceredigion & 69,500 & 179,399 & 14 & 32.6 & 26,438 & 276,421 \\
\hline Leicestershire & 927,500 & 255,087 & 91 & 362.0 & 707,888 & $5,188,114$ \\
\hline Liverpool & 468,000 & 11,292 & 28 & 270.0 & 623,935 & $2,065,359$ \\
\hline Manchester & 430,800 & 11,612 & 27 & 368.0 & 974,581 & $3,904,404$ \\
\hline Newcastle & 282,300 & 11,179 & 23 & 208.4 & 617,515 & $2,245,100$ \\
\hline Sheffield & 530,400 & 36,734 & 32 & 243.9 & 403,221 & $1,544,865$ \\
\hline Somerset & 482,700 & 345,200 & 43 & 175.0 & 495,391 & $3,382,521$ \\
\hline
\end{tabular}

1. No enquiries or visits figures available for Aberdeenshire

2. No figures available. Brighton and Hove became a unitary authority in April 1997, having formerly been part of East Sussex.

3. Liverpool staff figure is for actual staff in post. 


\section{Citizens Advice Bureaux}

The Citizens Advice Bureau is, of course, a familiar sight in most towns and cities, and the development of the UK network of Bureaux, since it was established at the outbreak of the Second World War, has been relatively well documented elsewhere (see, for example, Ward and Mason (1986)). Initially financed by the Ministry of Health, post-war funding was the responsibility of local councils. Indeed, local authorities still provide over $85 \%$ of $\mathrm{CABx}$ funding, although increasingly this is through contracts for service level agreements with bureaux being assessed against performance indicators. Additional finance can come from a range of private sector and charitable sources, and a number of bureaux have been beneficiaries of National Lottery funding.

CABx in England, Wales and Northern Ireland are coordinated and supported by the National Association of Citizens Advice Bureaux (NACAB) and by nine regional offices. Bureaux in Scotland, due largely to increasingly distinct regulatory and administrative needs, are served by a separate, autonomous body, Citizens Advice Scotland (CAS). Both NACAB and CAS receive most of their income from the Department of Trade and Industry.

$\mathrm{CABx}$ throughout the UK, including of course those participating in this research, share two common aims, namely:

to ensure that individuals do not suffer through lack of knowledge of their rights and responsibilities or of the services available to them, or through an inability to express their needs effectively

and equally

to exercise a responsible influence on the development of social policies and services, both locally and nationally

$\mathrm{CABx}$ are also governed by four basic principles, that the service they provide should be:

- Free

- Impartial

- Independent

- Confidential 
Seven $\mathrm{CABx}$ were visited during the project: Aberdeen, Aberystwyth and District, Central Belfast, Brighton, Charnwood (as part of the visit to Charnwood Community Council, see below), Manchester, and Peterborough and District.

\section{Other Information and Advice Agencies}

The other information and advice agencies participating in the project will be less familiar to most readers. With this in mind, a brief portrait of each one is presented here.

The Byker Advice and Information Project in Newcastle upon Tyne was established in 1993 with funding from Newcastle City Council, the local Training and Enterprise Council, and various charities and trusts. Originally envisaged as a welfare rights service, the Byker Project now also provides advice and information on other topics, including consumer issues and housing.

Formed in 1966, the Charnwood Community Council is a Council for Voluntary Service based at John Storer House in Loughborough. It is supported by grants and voluntary contributions from Leicestershire County Council, Charnwood Borough Council, and various charitable trusts and businesses. The Council provides an information service to local individuals, groups and organisations involved in community action, but is unusual in that it also operates a Tourist Information Centre. John Storer House also hosts the Charnwood CAB.

The Gordon Rural Action and Information Network (GRAIN) was established in 1979 and is the Council of Voluntary Service for Central Aberdeenshire. It has three generalist advice centres, in Ellon, Huntly and Inverurie. Funding for the advice centre division of GRAIN largely comes from an Aberdeenshire Council grant and from donations by charitable trusts.

The Langsett Advice and Area Resource Centre was formed in 1979 and provides generalist advice to residents of the Upperthorpe, Netherthorpe, Walkley and Stannington areas of Sheffield. Funding primarily comes from Sheffield City Council. 
Established in 1988, the Orrell Park Advice Centre in Liverpool provides information and advice to the residents of Orrell Park and the surrounding areas. Advice on disability benefits is a particular speciality. The Centre's main benefactor is Liverpool City Council, with additional finance coming, whenever possible, from charitable trusts.

The St. James Community Support and Advice Centre in Aston, Birmingham was established as a Christian project in the late 1970s by the Parochial Church Council of St. James. Around $90 \%$ of its users are from the local Sylheti and Mirpuri communities. The main sources of funding are Birmingham City Council and the Barrow Cadbury Trust.

The Turnpike Lane Advice Bureau is one of three advice and information centres operated by Haringey Council in London, the others being at Hornsey and Tottenham. As well as general information, the Bureau offers free advice on benefits, housing and debt.

The West Somerset Community Information Bureau in Minehead was formed in 1978, and in 1997 became the West Somerset Advice Bureau. The Bureau regards itself as equivalent to a $\mathrm{CAB}$, but without the backing or support of NACAB. Financial support chiefly comes from Somerset County Council and West Somerset District Council.

\section{Demographic features of areas served by case study organisations}

Representatives of the organisations were asked about local demographic factors that might have a significant impact on citizenship information need. Virtually all cited high levels of unemployment and an ageing population, and a significant number specified high concentrations of ethnic minority groups. Many of the organisations serve inner city areas, therefore general poverty, deprivation and homelessness are also common problems. A number of the areas displayed special characteristics. In Brighton, for example, the existence of a prominent gay community means that there is an equally prominent need for information on gay rights and HIV/AIDS issues. Aberdeen, due to the local oil industry, has a high proportion of contract and agency workers on insecure, short-term contracts, as well as particularly high housing costs, therefore financial problems and debt are rife. Somerset has substantial seasonal unemployment problems. The Belfast Group of CABx have had to deal with problems (e.g. dealing with the aftermath of bombings, or of residents being burnt or intimidated out of their homes) which other UK bureaux are less likely to encounter. 


\section{Catchment areas}

Most of the organisations are situated centrally within their particular town or city and tend to attract users not just from the immediate locality but also from the suburbs and further afield. Even those organisations established to serve a particular community, such as the Byker Project and the Langsett Centre, find that some clients come from outwith that area. Staff offered four reasons for this phenomenon.

Firstly, and most simply, there are no suitable information or advice providers in the 'incoming' users' own areas. Secondly, and generally applicable to those organisations in a central location, their users visit the town/city centre on a regular basis anyway, to work, shop or study. Thirdly, some users perceive a centrally located organisation as 'head office' in nature and capable of providing better information and advice than those organisations in the suburbs or 'the sticks'. Fourthly, some users, particularly of CABx and other advice agencies, do not want to be seen approaching their local organisation with a problem. As one $\mathrm{CAB}$ manager explained:

'They don't want to see people they know in the waiting room, and they're worried that the person who's dealing with them will be a next-door neighbour or friend.'

This was a phenomenon identified during previous research conducted by the authors on the information needs of the close-knit, rural communities of the Shetland Islands (Beer et al, 1998). However, during the current research, while it was certainly recognised by organisations serving predominantly rural communities, it was also identified by organisations in large cities (e.g. Belfast and Manchester), who believe that communities in, for example, city housing estates are equally close-knit, and may force individuals with problems to seek anonymity in bureaux and agencies in other areas.

\section{Extent of citizenship information provision}

\section{Information provision vs Advice}

The provision of accurate information and impartial advice is the raison d'être of those CABx and other advice agencies discussed here. However, during the late 1970s and early 1980s a debate arose as to whether public libraries, in providing a community/citizenship information service, should simply ensure the information is made available to the public, or should become involved in providing advice, counselling or advocacy. As Bunch (1988) 
explained, opinions were mixed: while some public librarians felt it was impossible to separate information from advice, others believed that libraries should retain a passive role. Moore and Steele (1991) observed that this debate led to a general consensus that public libraries should concentrate on the provision of factual information and on referral, rather than on the provision of an advice service.

In the vast majority of the case study libraries this was found to be the case, due largely to a lack of specialised knowledge, plus fears of possible repercussions should unreliable advice be given. The one exception is the Sheffield Information Service, part of Sheffield Libraries and Information Services. It consists of three services: a reception service for Sheffield Libraries; a city-wide information resource centre which gathers and distributes information on, for example, local clubs and organisations, city council services, statutory agencies and services, and further and adult education; and, most importantly in terms of the project discussed here, a generalist advice centre where trained staff provide information and advice on everyday problems including welfare rights, employment, housing, and family and personal matters. In the other twelve library authorities, meanwhile, the extent of and approach to citizenship information provision is varied, and this will be discussed in greater detail throughout this paper.

\section{Other services}

In addition to providing information and advice to members of the public at their premises, most of the $\mathrm{CABx}$ and other advice agencies carry out home visits to housebound clients living within their immediate locality, although these are open to abuse (in terms of being requested by physically mobile individuals claiming to be housebound) and so are not widely publicised. One bureau, in a predominantly rural area, also carries out visits to people who are not necessarily housebound but who live in remote locations with no public transport; again this service is not publicised. Amongst the library authorities, both Camden's Home Library Service and Newcastle's Housebound Readers Service can bring community information to the homes of housebound local residents.

Most of the CABx and other agencies also carry out representation work for clients at various courts and tribunals. These include Social Security Appeal Tribunals, Employment Appeal Tribunals, Disability Appeal Tribunals, Medical Appeal Tribunals, Industrial Tribunals, Immigration Appeals, Criminal Injuries Compensation Boards, Small Claims Courts, and Housing Benefit Review Boards. This is not a service provided by public libraries. 


\section{Staff}

Each of the $\mathrm{CABx}$ and other advice agencies visited has paid full-time and part-time (or jobshare) management, administrative and advice staff, although these vary greatly in number depending on the size of the organisation. The Aberystwyth $\mathrm{CAB}$ and the Langsett Centre, for example, have just two paid part-time workers each, while the Manchester CABx Service has a total of 52 staff in its nine bureaux. In many cases these staff are augmented by paid project workers, on fixed-term contracts, funded by external bodies. For example, Central Belfast $\mathrm{CAB}$ has two financial advice workers funded originally by the Allied Dunbar Charitable Trust and subsequently by Northern Ireland Electricity.

Most of the CABx and advice agencies also rely heavily on the services of unpaid volunteers. Of the 28,000 people in the CAB service in England, Wales and Northern Ireland, 90\% are volunteers (NACAB, 1996b). A recurring problem is that of attracting, and retaining, volunteer staff: most agencies reported a high staff turnover and a current deficit in volunteer numbers. One commonly cited reason for this high turnover was that employers hold $\mathrm{CAB}$ training and work experience in high esteem: many volunteers therefore use $\mathrm{CAB}$ work as a career 'stepping-stone'. There are mixed feelings about this phenomenon amongst CAB managers: whilst some find it decidedly frustrating, others are more positive, believing that ex-volunteers can usefully promote the $\mathrm{CAB}$ service or become important contacts, should they go on to work in other information and advice services.

With the exception of the Sheffield Information Service, which has a team of 11 full-time and 1 part-time staff to provide community information and advice, there are no dedicated community/citizenship information staff in the library authorities visited. Instead, community information services are coordinated by staff whose job descriptions encompass more general responsibilities; the job titles of these staff include Liverpool's Coordinator for Information and Development Services, and Somerset's Assistant County Librarian (Information Services). In three authorities - Aberdeenshire, Birmingham and Newcastle reviews of community information provision were currently taking place, therefore the appropriate staff were devoting more time to this area than might normally be expected. 


\section{Staff training}

$\mathrm{CABx}$ advisers throughout the UK all complete a basic training programme, devised by NACAB (and, in Scotland, CAS) and administered at regional and area levels. The programme covers the aims and principles of the $\mathrm{CAB}$ service, and looks at subjects such as benefits, housing, and consumer and debt issues; it also covers skills such as interviewing and case recording. While all of the case study $\mathrm{CABx}$ participate in this programme, the Manchester CABx Service has developed its own programme as a supplement; this looks at various topics, but has a particular emphasis on welfare benefits issues. Increasingly, $\mathrm{NACAB}$ and CAS offer specialist training courses which examine areas as diverse as advocacy and representation, employment law and income tax self-assessment, and all of the case study bureaux have participated in these. Interestingly, NACAB has recently undertaken a review of its training, which has developed into the Competency in Advice Giving Project - a plan to give $\mathrm{CAB}$ workers an externally accredited qualification that will parallel National Vocational Qualifications in advice work (NACAB, 1997). Most of the case study $\mathrm{CABx}$ have also taken part in external training courses, organised by national organisations such as Shelter (on housing issues) and the Equal Opportunities Commission (on equal opportunities law), or by local organisations or representative groups.

The training provision in the other advice agencies is largely a mixture of in-house programmes and on-the-job training. The West Somerset Bureau, for instance, operates an induction course similar to that of $\mathrm{NACAB}$, with self-learning modules on welfare benefits, housing, taxation, etc.; while the Byker Project operates a basic introductory course focusing on welfare rights devised by its paid Advice/Volunteer Support Worker, himself a former $\mathrm{CAB}$ worker. Some make use of external training courses, although financial restrictions can limit these opportunities: for example, Langsett Centre staff attend sessions organised by the Sheffield Advice Centre Groups, a network of local information and advice agencies and community and voluntary organisations.

In the majority of the library authorities visited, training in community/citizenship information provision does not receive much specific attention. The tendency instead is to include an introduction to community/citizenship information sources and enquiry work during staff induction programmes, and also to rely on on-the-job training. Most of the authorities also have a rolling training programme and some of them will occasionally cover community/citizenship information issues. Camden has run sessions on using their community information database; while Somerset (who carried out extensive training when 
their community information collections were established in the early 1990s, and still runs refresher courses when required) has organised events at which representatives of $\mathrm{CABx}$, social services, health authorities and employment services have discussed their services and the information resources they hold. Liverpool, meanwhile, has a community information skills module as part of their in-house information skills training package. Most significantly, though, staff at the Sheffield Information Service attend the Sheffield Advice Centre Groups' (SACG) training courses, which include sessions on welfare benefits, council tax, housing and debt, as well as interviewing, advocacy and negotiating skills. Sheffield are not charged for this training, but instead make payment 'in kind' by providing SACG members with information from their various databases.

\section{Staff with ethnic minority language and sign language skills}

The organisations visited are located throughout the length and breadth of the UK and, as such, serve areas with varying concentrations of ethnic minority groups. Some areas, such as Aberdeenshire and Somerset, have relatively few residents from minority groups, therefore the organisations located there feel little need to employ staff with minority language skills to provide citizenship information and advice. Although interestingly, Aberdeen CAB has recently recruited more volunteers from ethnic minority groups and has found that the number of clients from minority groups has also risen, due, it is believed, to news of this support being quickly spread throughout these close-knit communities.

Some areas contain perhaps only one or two concentrated populations of particular ethnic groups, and the organisations within these areas have had to decide whether their presence and level of use of the service requires the employment of staff with special language skills. Peterborough $\mathrm{CAB}$ has an Italian-speaking welfare rights adviser who deals with the large local Italian community; however, the two Belfast organisations visited feel no real need to employ staff specifically to deal with the local Chinese community, particularly as they tend to obtain information and advice from a local Chinese Welfare Society. Some case study organisations with little or no minority language provision find that clients with little or no English will bring English-speaking family or friends to help them translate their problems and needs; while others have used, or are aware of the potential to use, their local council's translation and interpretation service.

A number of the organisations, however, serve areas with high concentrations of minority groups and have found it essential to employ staff with special language skills. The St. James 
Centre in Birmingham has staff who speak Punjabi, Mirpuri, Bengali, Sylheti, Hindi, Gujarati and Urdu; while staff at the Turnpike Lane Advice Bureau in London speak Amharic, Arabic, Bengali, Cantonese, French, Greek, Somali and Turkish. Manchester Central Library contains a Chinese Library, with community information available in both Chinese and English; and Liverpool Libraries have a Multiracial Library Promotions Unit, whose aims and objectives include "to investigate the library and information needs of Liverpool's Black community" (Liverpool Libraries \& Information Services, 1997). Sheffield Libraries have four posts working specifically to raise awareness and improve accessibility to information for the local Bangladeshi, Pakistani, Chinese and Afro-Caribbean communities.

In the two Welsh organisations visited, the provision of information and advice in the Welsh language is an increasingly important issue. Ceredigion County Council has a bilingual policy, and council minutes and agendas, as well as leaflets from central government departments and agencies, are available in both English and Welsh. The vast majority of staff in the Ceredigion library service speak Welsh, and the Aberystwyth and District CAB has around 10 Welsh speakers. With regard to other indigenous languages in the UK, it should be noted that in the area of Scotland surveyed - the North East - Scottish Gaelic is not a particularly prominent language; while in Belfast, although there is an increasing interest in the Irish language, this tends to focus on literature and does not yet impinge on citizenship information provision.

On a similar theme, a small minority of case study organisations have staff with basic British Sign Language skills. The others are generally able to call upon the assistance of external organisations and individuals, should a need arise. Manchester $\mathrm{CABx}$, for instance, can take advantage, free of charge, of a Manchester City Council contract with sign language interpreters.

\section{Types of citizenship enquiries received}

Only two of the library authorities could offer any kind of statistical information on the frequency and type of community/citizenship enquiries received.

During 1996-97, the generalist advice service of the Sheffield Information Service dealt with 3,191 advice enquiries, broken down into the following categories: Social Security (29.5\%), Consumer (18.3\%), Housing (14.3\%), Employment (10.2\%), Family (10.2\%), Administration of Justice (5.9\%), Debt (3.1\%), Taxes (2.3\%), Travel and Transport (1.4\%), Human Rights 
(1.3\%), Education (1.0\%), Health (0.9\%), Immigration and Nationality (0.9\%), Communications $(0.6 \%)$ and Leisure $(0.1 \%)$.

Leicestershire Libraries and Information Service, meanwhile, found that of the 4,172 enquiries received in their libraries during one week in March 1994, 14.9\% were for local information, $8.0 \%$ for tourist/travel, $4.1 \%$ for education/careers, $2.3 \%$ for 'Help!' information (i.e. on disability, health, welfare rights, immigration, etc.) and $1.7 \%$ for information on the local council.

The other library authorities, though, have no mechanism for recording these types of enquiry and could therefore only offer impressionistic rather than real data. The point was made that many of the community information collections are of the 'self-help' kind, therefore it is difficult to gauge accurately the extent and nature of their use. There was widespread agreement that information on educational opportunities and issues, employment opportunities and careers, and local council information were the most popular topics. Legal, environmental and health care information were also prominent. There were fewer, but still significant, demands for information on leisure and recreation, national government, welfare benefits, the European Union, transport, consumer issues, housing, family/personal matters, taxation, and health and safety.

Enquiries in all UK CABx, however, are systematically recorded under a uniform set of subject headings, and those of six of the case study bureaux, together with national figures (NACAB, 1996b; CAS 1996b), can be seen in Table 2. 


\begin{tabular}{|c|c|c|c|c|c|c|c|}
\hline \multicolumn{7}{|c|}{$\begin{array}{l}\text { Table 2: Categories of problems brought to case study CABx - \% of totals (1996/97 unless } \\
\text { otherwise stated) }\end{array}$} & \multirow[b]{3}{*}{$\begin{array}{c}\text { UK-wide } \\
(6,956,459)\end{array}$} \\
\hline & \multicolumn{6}{|c|}{$\begin{array}{c}\text { Bureaux } \\
\text { (and total number of enquiries received) }\end{array}$} & \\
\hline Categories & Aberdeen $^{1}$ & $\begin{array}{l}\text { Aberystwyth } \\
(7,943)\end{array}$ & $\begin{array}{c}\text { Brighton } \\
(12,431)\end{array}$ & $\begin{array}{c}\text { Charnwood } \\
(35,307)\end{array}$ & $\begin{array}{l}\text { Manchester } \\
(\mathbf{7 5 , 5 7 2 )}\end{array}$ & $\begin{array}{c}\text { Peterboro'2 }^{2} \\
(42,243)\end{array}$ & \\
\hline Benefits & 13.0 & 20.8 & 26.5 & 17.8 & 40.2 & 19.4 & 28.8 \\
\hline $\begin{array}{l}\text { Consumer \& } \\
\text { Credit } \\
\text { (inc. utilities) }\end{array}$ & 42.0 & 23.5 & 13.5 & 23.8 & 19.9 & 31.7 & 17.0 \\
\hline Employment & 13.0 & 8.6 & 10.9 & 14.8 & 6.4 & 16.4 & 10.2 \\
\hline Housing & 8.0 & 12.4 & 16.2 & 10.3 & 10.0 & 8.6 & 11.0 \\
\hline Legal & 7.0 & 8.6 & 10.1 & 7.9 & 7.0 & $13.1^{3}$ & 9.5 \\
\hline Relationships & 5.0 & 6.8 & 8.0 & 9.3 & 3.5 & & 7.6 \\
\hline Taxes & 7.0 & 3.9 & 3.2 & 5.1 & 5.3 & 2.1 & 3.9 \\
\hline Other $^{4}$ & 5.0 & 15.2 & 11.8 & 11.1 & 7.7 & 8.7 & 12.0 \\
\hline
\end{tabular}

1. 1997-98 figures

2. 1995-96 figures

3. Combined total for Legal and Relationships

4. 'Other' includes: Community Care, Education, Health, Immigration, Nationality, Miscellaneous and Signposting.

Meanwhile, the top six categories of enquiry at the five bureaux in the Belfast Group of CABx, in the five year period between 1990-94, were: Social Security (48\%), Consumer (15\%), Other (15\%), Housing (9\%), Personal (7\%), and Justice (6\%).

As can be seen, welfare benefits and consumer issues (largely consumer debt) are the two biggest categories nationally, and that in the majority of case study bureaux they also occupy the top two places. The two exceptions are Aberdeen, where employment issues are on an equal footing with benefits information, and Brighton, where housing replaces consumer matters as the second most important issue. While benefits is by far the biggest national category, consumer/debt problems are ranked first in the Aberdeen, Aberystwyth, Charnwood and Peterborough bureaux.

While two of the other advice agencies use the NACAB/CAS categories for statistical analysis, the others have developed their own subject headings. As a result, it is not possible to present this information in tabular form. The enquiry statistics of each agency, where available, are therefore simply listed below. Again, welfare benefits and consumer/debt are the most prominent issues, although housing problems obviously form an important part of the Orrell Park Centre's work; while at the St. James Centre in Birmingham (which, as 
already stated, is used largely by the local Sylheti and Mirpuri communities) immigration matters form a major part of the workload.

Byker Advice and Information Project, 1996-97 (1,432 enquiries)

Benefits (61.2\%), Consumer (7.7\%), Employment (2.4\%), Housing (7.1\%), Legal (3.3\%),

Relationship (1.5\%), Taxation (3.8\%), Utilities (2.3\%), Other (10.7\%)

\section{Charnwood Community Council Information Centre, 1995-96}

Answered 36,852 enquiries, including those dealt with by the Tourist Information Centre, but no precise breakdown available.

\section{Gordon Rural Action and Information Network, 1997-98}

The three GRAIN advice centres dealt with a total of 6,666 enquiries. No detailed breakdown was available, although welfare benefits and money advice were the two main topics encountered.

Langsett Advice and Area Resource Centre, 1996-97 (6,672 enquiries)

Benefits (43.5\%), Consumer and Debt (11.3\%), Housing (10.2\%), Local Information (9.9\%), Taxes and Duties (6.0\%), Legal Advice (4.5\%), Employment (3.2\%), Family and Personal (2.9\%), Health (2.1\%), Travel, Transport and Holidays (1.7\%), Family and Community Services Queries (1.5\%), Education (1.0\%), Local and Central Government $(0.8 \%)$, Immigration and Nationality (0.7\%), Communications $(0.5 \%)$, Leisure $(0.2 \%)$

Orrell Park Advice Centre, 1996-97 (4,102 enquiries)

Welfare Benefits (34.5\%), Housing (17.1\%), Referrals (13.8\%), Appeals and Reviews (11.3\%), Debt (5.6\%), Employment (3.7\%), Consumer (3.1\%), Legal (1.6\%), Miscellaneous (9.1\%)

St. James Community Support \& Advice Centre, 1995-96 (13,700 enquiries)

Welfare Benefits (41.2\%), Immigration (28.8\%), Debt (12.5\%), Housing (7.5\%), Legal (5.0\%), Miscellaneous (3.7\%), Personal (1.2\%)

\section{Turnpike Lane Advice Bureau}

No figures available. 
West Somerset Advice Bureau, 1996-97 (5,936 enquiries)

Benefits (40.6\%), Consumer (13.8\%), Employment (7.0\%), Housing (11.3\%), Legal (9.4\%), Relationship (5.8\%), Tax (3.4\%), Utilities (2.3\%), Other (6.3\%)

\section{Public's preferred methods of contacting service and obtaining information}

Few organisations could provide anything other than impressionistic data regarding the ways in which the public make their enquiries.

Leicestershire Libraries, as part of their 1994 survey of all information enquiries, found that $83 \%$ of enquiries were made in person, $16 \%$ by telephone, and $1 \%$ by letter or fax.

In 1996-97, Aberystwyth CAB found that 58.0\% of its clients made contact in person, 34.7\% by telephone, $7.3 \%$ by letter, and just $0.1 \%$ by fax/other. These are remarkably close to national figures for 1995-96, which indicated that 54\% of CABx users made contact in person, $36 \%$ by telephone, $7 \%$ by letter, $1 \%$ by fax, $1 \%$ by home visit, and $1 \%$ by representation at a court or tribunal (NACAB, 1996b).

The West Somerset Advice Bureau, meanwhile, found that $60.6 \%$ of their clients in 1996-97 were personal callers, $35.8 \%$ used the telephone, $2.2 \%$ made contact by letter, $1.1 \%$ were visited at home, and $0.3 \%$ made contact during representation at a tribunal.

The trend was similar in the other organisations, with the majority of enquiries made in person, a smaller but significant proportion made by telephone (greater in the CABx and other agencies than in the libraries), and a small number by letter or fax. The one exception appeared to be Peterborough $\mathrm{CAB}$, where it was estimated that the number of telephone enquiries was equal to the number of personal callers. Indeed, in several of the $\mathrm{CABx}$ it was suggested that the number of telephone enquiries could potentially be far greater than it currently is; however, bureaux often simply do not have the staff to answer telephone enquiries and deal with personal callers. In fact, the Central Belfast CAB is taking the step of reducing its opening hours to personal callers by $50 \%$ so that it can deal more effectively with telephone enquiries.

Interestingly, the Manchester $\mathrm{CAB}$, in a 1995 user survey, asked 239 users their preferred way of getting advice from the $\mathrm{CAB}$, if they were given a choice. The vast majority (97\%) 
said they would prefer face-to-face contact with someone, with $51 \%$ preferring a personal visit with an appointment, $40 \%$ preferring to drop in to the $\mathrm{CAB}$ and wait their turn, and $6 \%$ preferring a home visit. Only $2 \%$ of respondents said they would prefer to contact the $\mathrm{CAB}$ by telephone, while writing a letter was the choice of just $0.5 \%$.

The general feeling amongst staff in the organisations visited was that face-to-face contact was indeed the public's preferred method of obtaining information and advice:

'People prefer a face-to-face interview with a person who appears to be listening to what they're saying. Even if we haven't done anything for them...the mere fact we've listened without butting in or being judgemental, and then shown them information in plain English explaining that what they'd been told 'officially' was correct, then they go away happy. Obviously the ones we can help are even more grateful. I think people still prefer to see someone face-to-face, taking their time, and getting the opportunity to ask questions.'

Telephone contact was perceived as a less popular method, but extremely useful if the client/user wished to retain his/her anonymity:

'Sometimes I think people phone us in preference to calling in, because they want to be anonymous - which is perfectly okay, we don't pressurise people to give us their names. Sometimes I'm amazed how much personal and intimate information people will give over the phone to a complete stranger, but I guess that's because it's easy to do it to a complete stranger. It's much harder to confide something like that to somebody you know well'.

It was also indicated that telephone contact was preferred by those with access problems, in terms of either geography or physical disability. Interestingly one $\mathrm{CAB}$, when conducting a recent community profile, found that more women used the telephone service than visited the $\mathrm{CAB}$ in person As the (female) adviser indicated:

'I tend to find women's telephone enquiries concern relationships and sensitive stuff. I think most ladies would say the telephone's our first port of call - you can be totally anonymous.' 
Whilst telephone contact might be preferred by some users, the staff of the $\mathrm{CABx}$ and other advice agencies feel a more thorough job can be done if the users visit in person:

'A lot of our enquiries are by phone. This isn't good, because we'd prefer to meet the client. In some instances we'd do half of it by phone then advise them to come in and bring their paperwork with them, so we could sit down and talk them through it.'

Similarly, whilst advice staff acknowledge that there are members of the public who would prefer to simply take away a leaflet, this is discouraged, as it is felt that basic leaflets may fail to meet the users' actual needs, which might be more fully explored with a face-to-face interview:

'Sometimes they say they want a leaflet on redundancy, but if you actually talk to them they might have a case for unfair dismissal, and they might not know that by reading a leaflet...'

\section{User studies and studies of information needs}

Only four of the organisations had conducted recent surveys of their users and/or their citizenship/community information needs.

The Manchester CABx Service, in its 1995 survey (of 239 people), found a female-male ratio of $43 \%-57 \%$. With regard to age group, $10 \%$ were aged $16-24,40.5 \%$ were $25-44,25 \%$ were $45-59$, and $24 \%$ were aged 60 or over; just $0.5 \%$ were under 16 . With regard to status, $35 \%$ were sick or disabled, $17 \%$ were looking for work, and $14 \%$ were carers; $39 \%$ lived alone, and $15 \%$ were single parents; $23 \%$ were from an ethnic minority group, and $50 \%$ lived in council housing. Respondents were asked to think about their own needs, and suggest improvements to the $\mathrm{CAB}$ service. While $46 \%$ said no improvements were necessary, $17.4 \%$ wanted additional advice sessions in, for example, surgeries and community centres, 17\% requested child care/crèche facilities, $11 \%$ wanted better physical access, 5\% asked for information in Braille, large print or audio tape, $3 \%$ required a language interpreter, a further $3 \%$ wanted materials in other languages, and 3\% asked for a signer or induction loop. Interestingly, the Manchester survey also included some questions on the potential use of ICTs. Respondents were asked where they would like public information kiosks with easyto-use screens to be set up. The top responses were: libraries $47 \%, \mathrm{CABx} /$ advice centres $38 \%$, shopping malls $38 \%$, doctors' surgeries $36 \%$, supermarkets $30 \%$, bus station $24 \%$, 
neighbourhood centres $23 \%$, community centres $20 \%$ and town hall $20 \%$. When asked if they would expect to pay anything for using these kiosks, $69 \%$ said they would not.

The Byker Project, meanwhile, conducted a Client Group Survey in 1995 and discovered a female-male ratio of 53\%-47\%. All of its clients were white, with $13 \%$ aged under 24 , and $17 \%$ aged 65 and over; 70\% were on benefit and 55\% in receipt of Income Support. Less than $10 \%$ were in full-time work, while $2 \%$ were in part-time work; $34 \%$ were unemployed, $30 \%$ saw themselves as long-term sick, and $20 \%$ were retired; $27 \%$ were disabled, and $22 \%$ were single mothers. Some $83 \%$ lived in council accommodation, and $67 \%$ had come to the Project seeking advice on benefits.

Birmingham Libraries conducted a survey of 1,309 Central Library adult users in 1995. Of these, $44 \%$ said they were "looking for information". When asked about the reasons for their visit, $53.8 \%$ said they were using the library for education and study, $36 \%$ for leisure, $14.3 \%$ for hobbies and personal pursuits, and $4 \%$ for help in finding work.

As part of its 1994 survey of information enquiries received in their libraries, Leicestershire Libraries estimated that around $13 \%$ of their enquiries were from people aged under 17, with a total of $39 \%$ of enquirers being under 24 ; in contrast just $9 \%$ of users of the information service were 'elderly people'. It discovered that $22.9 \%$ of all information enquiries were related to an academic study or school project. On comparing age group with the nature of the enquiry, it was found that young people most frequently requested information on education and careers; information on local studies and travel/tourism was more popular with older users; while business information featured most across the 'middle' age groups.

The other organisations could only provide impressionistic data on users and user needs. Although the Orrell Park Centre estimates that around 80\% of its clients have some form of disability, and $90 \%$ of the St. James Advice Centre are from ethnic minority groups, most feel that their service is used by a cross-section of the population. Interestingly, five of the $\mathrm{CABx}$ and other agencies feel that their service is used least by the very young (i.e. aged 21 and under), perhaps because they prefer to go to organisations who specifically deal with young people's problems. In contrast, three of the library authorities feel that use of their community information collections is increasing amongst schoolchildren and students carrying out project work. 


\section{User satisfaction with citizenship information provision}

Studies of user satisfaction in the case study organisations were also relatively rare. Birmingham Libraries examined user satisfaction as part of their 1995 user survey, and while this applied to the entire Central Library two of the resultant 'Areas for Action' impinge upon their citizenship information provision, namely that there should be increased promotion of relevant resources to independent learners, and to jobseekers and those interested in career development and training opportunities. Liverpool Libraries, meanwhile, hold regular user forums in their Central and Community libraries; while these can deal with any aspect of their service, the community information service, and in particular the range of leaflets held, has been discussed and acted upon.

None of the generalist advice agencies had carried out a user satisfaction survey. While a small number make comments/suggestions cards available, it is found that these are rarely completed, for as one adviser observed: “they've enough trouble with the official forms they've to fill in". Instead, the most common, if imprecise, measure of user satisfaction is the number of thank you cards and small gifts they receive from grateful clients.

Every 3 years, each $\mathrm{CAB}$ has to complete a Membership Review Report, for either NACAB or CAS, and this generally includes a survey which asks users for their impressions of, for example, the accessibility and comfort of the premises and the waiting time. However, due to doubts over whether these reports should be in the public domain, and to simple unavailability, only two bureaux could provide copies of these. The impression given by the interviewees in this study, though, was that clients are generally very satisfied with the advice given, with the most common complaints being about the waiting time involved. The high level of satisfaction with advice given can be illustrated with the results of a recent survey, independent of the Membership Review scheme, conducted by Brighton CAB. In this survey, of 67 clients, $99 \%$ felt confident that the adviser was able to answer their query, $96 \%$ knew what action to take after leaving the bureau, and $96 \%$ felt they would recommend the bureau to anyone with similar problems.

\section{Citizenship information sources and arrangement}

For all $\mathrm{CABx}$, the NACAB Information System is by far the most important information source. Updated monthly by staff in the central offices of NACAB and CAS, the information system consists of some 12,000 pages arranged within the following basic subject headings:- 
1. Communications

2. Travel, Transport \& Holidays

3. Immigration \& Nationality

4. Administration of Justice

5. Education

6. Employment

7. National and International
8. Family and Personal

9. Social Security

10. Health

11. Housing, Property and Land

12. Taxes and Duties

13. Consumer, Trade and Business

14. Leisure

This is supplemented by a range of textbooks and other sources, some provided along with the Information System by NACAB and CAS, others purchased individually by the bureaux. Among the more useful sources cited were the National Council for Voluntary Organisations' (NCVO) Voluntary Agencies Directory, and the Institute of Development Studies' Policy Briefings; however, a mainstay for all bureaux are the Child Poverty Action Group (CPAG) handbooks, such as the Child Support Handbook, the Council Tax Handbook, the Debt Advice Handbook, and the Jobseeker's Allowance Handbook. Local information, particularly contact details for local groups and societies, is also important.

Of the other, generalist advice agencies, four - the West Somerset Bureau, the Langsett Centre, the Byker Project, and GRAIN - subscribe to the NACAB/CAS Information System; although, at the time of the visit, GRAIN was to be severely affected by a CAS decision to withdraw its information system from non-CAB advice agencies throughout Scotland in March 1999, unless they applied to become a CAB. (Interestingly, a similar proposal for the rest of the UK was rejected by NACAB on the grounds that it could compromise their grant from the Department of Trade and Industry (Computanews, 1998)). Other useful sources cited by the generalist agencies include the Department of Social Security's Adjudication Officers' Guide, and the Social Security and Child Support Commissioners' Commissioners' Decisions; and all of the agencies also rely heavily on the CPAG handbooks. Some also subscribe to journals such as The Adviser, Counterclaim, Money Advice and the Welfare Rights Bulletin; while all agencies also maintain files of local information.

With the exception of Sheffield Central Library, which has its own discrete advice service complete with enquiry desk and interview cubicles, the central libraries in the case study authorities can be divided into two distinct groups: those whose citizenship/community information materials are dispersed throughout the library's standard classified sequence, and those who have gathered together these materials to produce a distinct community information collection. The first group comprises Belfast, Ceredigion, Manchester and 
Newcastle (although it should be noted that Sheffield, in addition to its advice service, has citizenship sources scattered throughout its reference libraries), while the second group consists of the remaining authorities. The second group can be further sub-divided into those authorities whose collection consists of reference and/or lending copies of monographs and leaflets/pamphlets (Birmingham, Cambridgeshire, Camden and Leicestershire), and those whose collection is almost entirely leaflet/pamphlet based (Aberdeenshire, Brighton and Hove, Liverpool and Somerset). These collections are located in a general reference library except in Birmingham (Social Sciences Library), Camden (Lending Library) and Liverpool (where it used to be in the Commercial library, but where there are now plans to locate it just inside the Central Library's front entrance). With the exception of Ceredegion, all authorities also have small community/citizenship information collections in their branch/community libraries; these are often simply leaflet-based.

In those authorities with distinct community information collections, the tendency has been to create their own subject arrangements, rather than use a parallel sequence of the standard classification. Two examples are provided below.

Birmingham's Community Information section:-

Your rights and the Law

Welfare benefits

Employment

Health \& Safety

Transport \& Travel

Personal Finance

Housing

Family \& Personal
Young people

Retirement \& Elderly

Race \& Immigration

Consumer affairs

Disability

Voluntary organisations

Women

Leicestershire's 'Help!' collections:-

$\begin{array}{ll}\text { Community Action } & \text { Over 60s } \\ \text { Consumer Advice } & \text { Personal \& Family } \\ \text { Disability \& Handicap } & \text { Race relations } \\ \text { Environment } & \text { Unemployment } \\ \text { Health } & \text { Welfare rights }\end{array}$




$\begin{array}{ll}\text { Housing \& Property } & \text { Women } \\ \text { Immigration } & \text { Work } \\ \text { Law \& Civil rights } & \text { Young people } \\ \text { Money } & \end{array}$

Two of the library authorities - Birmingham and Sheffield - subscribe to the NACAB Information System (at a current start-up cost of $£ 1070$, plus $£ 840$ p.a. updating subscription), while several subscribe to NACAB's Basic Pack (a condensed version of the Information System, costing $£ 104$ to set up, plus an $£ 81$ p.a. updating subscription) and/or the NCVO Citizens Advice Notes Service (CANS). The range of monographs and textbooks held by the library authorities is too diverse to discuss here, but among the more useful sources cited were Charities Digest, The Civil Service Year Book, Croner's Employment Law, The Directory of British Associations, Dod's Parliamentary Companion, and Whitaker's Almanack. The CPAG titles were again considered invaluable.

The range of leaflets/pamphlets held in the library authorities' community information collections is equally diverse, ranging from those produced by central government departments/agencies and national organisations, such as the Benefits Agency and the Department of the Environment, to those produced by local groups and organisations, such as the Cambridgeshire Mediation Service and the Sheffield Drug Action Team. Seven of the case study authorities subscribe to Camden Information Service's Free Leaflet Information Service (FLIS) - a national service which provides information about the availability of free self-help information leaflets, and which identifies new titles, new editions, and old titles requiring withdrawal. Indeed, at September 1997, 85 UK library authorities were subscribing to this service, at a cost of $£ 190$ p.a. (Camden Information Services, 1997). In addition to those authorities with reference collections of leaflets, all of the case study authorities have community/citizenship information leaflets dispersed throughout their buildings for users to take away, as indeed do all of the case study organisations.

A number of the library authorities, in addition to their community information collections, have special collections which can certainly be described as containing citizenship information, some of them established with funding by, or in partnership with, external organisations. For example, Newcastle, in partnership with Tyneside Careers, have an Educational Guidance Unit, containing prospectuses, careers guidebooks and directories etc., and which hosts public drop-in sessions with careers service workers; Cambridgeshire has a 
similar arrangement with Cambridgeshire Careers Guidance. Camden has a 'Drugs: the facts' section, established in partnership with the Home Office Drugs Prevention Initiative. Birmingham, Cambridgeshire and Somerset have environmental information collections; Birmingham has an HIV/AIDS collection; while Somerset has a Disability Resources section. The majority of authorities have open learning collections.

Four authorities - Cambridgeshire, Camden, Leicestershire and Somerset - have what might generically be called council information points, containing local council minutes, agendas, reports, plans, and information on council services. Two of Somerset's information points, in Burnham and Frome libraries, have enquiry desks manned by council staff; while the Cambridgeshire and Camden equivalents have courtesy telephones (and in Cambridgeshire, a fax machine also) with which users can make free calls to local council departments. Liverpool Central Library has a Municipal Research Library Service which provides information, research and current awareness on local government issues; whilst aimed primarily at local authorities and councillors, it is also used as a resource to answer enquiries from the public.

\section{Electronic sources and use of Information and Communication Technologies}

Amongst the $\mathrm{CABx}$, whilst the use of Information and Communication Technologies (ICTs) for administrative purposes is commonplace, their use for information retrieval and provision is less so. Aberdeen and Aberystwyth CABx use software packages that calculate benefits entitlements, including the Imperial College School of Medicine's Lisson Grove Benefits Program. Aberdeen also has access to the Grampian CareData database of local health, social services and community information.

However, Manchester CABx Service has been to the forefront of technological developments in $\mathrm{CABx}$ and, in 1995, was the first UK CAB to establish its own Web site. Through this site, users can access an Update bulletin board containing new items on legislative changes taken from NACAB's monthly Update publication; as well as a searchable Citizen-Advice database containing all news items previously available on the bulletin board. All Manchester bureaux now have an e-mail address, and the Blackley CAB is currently taking part in a pilot scheme which allows members of the public to submit basic enquiries by email, with priority being given to those from the Manchester area. The Blackley and Harpurhey bureaux contain terminals with access to community information (i.e. job vacancies, training courses, council services, health services, details of voluntary 
organisations, etc.) provided by the Manchester Community Information Network - an alliance of local information providers including the City Council, $\mathrm{CABx}$ and other advice agencies, health centres and voluntary organisations - although public use is always supervised and aided by an adviser. (Indeed, because of fears of theft and vandalism, many of the CABx and other agencies felt it unlikely that they would ever have public access ICTs left unattended in their waiting rooms, or that they would even openly advertise the existence of ICTs in their buildings). The Manchester CABx Service has also played a key role in developing the Electronic Immigration Network - a web-based source launched in 1998 which aims to link major information providers with advice workers and practitioners dealing with all issues relating to immigration, refugee and nationality law and practice in the UK.

Meanwhile, with the aid of $£ 250,000$ from European Union Structural Funds, all bureaux in Northern Ireland, including of course the Belfast CABx, now have hardware and software which allow advisers to access an electronic version of the Information System, a statistical recording system, a case recording and management system, a distributed bulletin board system and a bureau-to-bureau e-mail system (Computanews, 1997). The new system has not been without its teething troubles, however, and as access is limited to two computers in each bureau, advisers still rely heavily on the paper copy of the Information System. At a national level, having already had a bid for Millennium Commission funds rejected, NACAB are hopeful that their CABnet 2000 project will eventually become a reality (NACAB, 1997). This project aims to network the $\mathrm{CAB}$ service throughout the UK and introduce an electronic version of the Information System. NACAB have developed a proposal for public/private partnership funding, and an electronic version is currently being piloted, on CD-ROM, in bureaux throughout the country.

In the generalist advice agencies, the situation is similar to that in the CABx, with ICTs being used largely for administrative work. The Langsett Centre has its own basic web page; while the Charnwood Community Council has had a major role in developing the Charnwood Online web site, which contains links to local councils, educational establishments, clubs and societies etc., as well as a searchable CHAIN (Charnwood Information Network) database of local voluntary and community groups. The West Somerset Advice Bureau uses a Ferret program for calculating welfare benefit entitlement.

In the public libraries, meanwhile, the most common use of ICTs for community/citizenship information provision is for what might generically be called the community information database, compiled either within the library authority itself or at a corporate (i.e. local 
authority) level. Brighton and Hove (ESCIS, i.e. East Sussex Community Information Service), Cambridgeshire (Infocam), Camden (Cindex), Leicestershire (Infolinx), Manchester (INFORM), Newcastle (Metronet), Sheffield (Community Resource), and Somerset (Community Information System) all have such a database. These can be on stand-alone systems or integrated in the library's OPAC; Manchester and Cambridgeshire's databases are also available on their respective websites. At the simplest level, they contain details of local societies and organisations; at the more detailed level, they also contain information on training opportunities, local council services, tourist information, health information, or information on benefits and entitlements.

Five of the library authorities have Training and Enterprise Councils' Training Access Points in a number of their service points; these contain information on training and education opportunities. Leicestershire and Sheffield have CASCAiD's Adult Directions program, which suggests careers based on the user's work and personal interests and chosen occupational level. Sheffield has an environmental information database at its Upperthorpe Library, while its Central Library has the FunderFinder program which identifies charitable funding opportunities. Somerset has the DissBASE database, produced by the Somerset Disability Information Federation, which contains both local and national disability information; while Manchester's Crumpsall and Moston Libraries have terminals with access to the Manchester Community Information Network databases described above. Aberdeenshire's HQ hosts the administrative team who compile the aforementioned Grampian CareData database, and terminals with copies of the database are available in each of its 36 branch libraries.

Seven of the 13 authorities provide public Internet access, while a number of the others are currently in the process of introducing the same. Use of these terminals, however, is not monitored in any great detail, so the extent to which the public use them to obtain citizenship information is not known. Cambridgeshire, though, provides a public access terminal specifically linked to the Cambridge Online City website which itself contains community information and links to information, advice and support agencies. Manchester, meanwhile, is part of the European Commission funded TARDIS research project aimed at enabling people to obtain information from touch-screen kiosks in public places. As part of this project, Manchester's Central and Wythenshawe Libraries host MAGIC (Manchester Gateway to Information for the Community) TOUCH kiosks. As well as community information from Manchester Community Information Network, the kiosks allow access to a range of web-based sources, including WorkWeb (a job search site), news and sport from the 
Press Association, and entertainment pages from Virgin Net. At the time of the visit, however, Manchester Central Library was having significant problems with the system, which was prone to 'freezing'.

Two of the libraries are making interesting use of videotelephony technology. Newcastle's Educational Guidance Unit contains a Virtual Careers Centre which, as well as providing career-choice software, allows remote access via videotelephony technology to a Tyneside Careers adviser. Camden, meanwhile, is taking part in the EU-funded TeleCommunity project: three videotelephony links, in Holborn, Kentish Town and Swiss Cottage libraries, allow people with hearing difficulties to access information about council services by interacting with an information officer with sign-language skills based at St. Pancras Library, who will answer queries and interpret between enquirers and service providers.

\section{Production of citizenship information materials}

A significant minority of the organisations have produced their own citizenship information materials. In the library authorities the trend has been to produce resources based on the contents of their community information databases. Camden produces lists taken from their Cindex database, including Camden Councillors' Advice Surgeries and Housing Associations and Co-operatives in Camden; Sheffield publishes a Help Yourself directory of voluntary agencies, taken from their Community Resource database; Leicestershire, in collaboration with Charnwood Community Council, produces lists such as Disability Organisations for Charnwood and Self Help and Support Groups for People in Charnwood; while Ceredigion publishes a List of Clubs and Societies in Ceredigion. Sheffield also publishes titles aimed at local ethnic minority communities, including the Sheffield Chinese \& Vietnamese Directory and the Sheffield Pakistani Directory; these provide details, in English and the appropriate minority language(s), of local representative groups and information and advice agencies.

With regard to the $\mathrm{CABx}$ and other agencies, a small number have produced self-help information packs on particular topics. The West Somerset Bureau has produced packs on debt and starting your own business; Brighton $\mathrm{CAB}$ has also produced one on debt; and Peterborough $\mathrm{CAB}$ has produced packs on a range of topics, including alcohol abuse, maternity, and funding for voluntary groups. A number have produced leaflets/pamphlets on particular topics: Aberdeen $\mathrm{CAB}$ has published items on bankruptcy and protected trust deeds; GRAIN has published a pamphlet on welfare benefits eligibility; and Manchester CAB produced a series of Good Parenting leaflets (also available on its website) as part of a 
special Parent Advice project. Manchester $\mathrm{CAB}$ also produced an information leaflet in response to the IRA bombing of central Manchester in 1996, which covered issues such as insurance, personal injury and loss of employment as a result of the explosion.

\section{Social policy work and research}

All $\mathrm{CABx}$ in the UK network undertake what is termed social policy work, where advisers identify significant issues and problems brought into the bureaux and, using evidence forms, report these to NACAB and CAS. NACAB receives 2,000 of these evidence forms each month (NACAB, 1997) and these are used as the basis for its social policy reports and press activity. Amongst the case study bureaux, the topics identified and reported have included problems with the Benefit Agency's telephone enquiry system and with British Gas' metering and billing procedures. Some bureaux have established their own social policy groups to identify, discuss and act upon local social policy issues. The Manchester CABx Social Policy Group, for example, monitored the discretionary Social Fund, as a result of receiving large numbers of enquiries from clients who had been refused a payment. Their resultant report Falling Through the Net is available on the Manchester CABx website. This is a very useful, proactive form of service helping to develop policy.

Some of the CABx have also occasionally participated in other, independent research projects. Brighton $\mathrm{CAB}$ monitored incidences of domestic violence as part of research being conducted by Sussex University, while Peterborough CAB carried out similar work on behalf of a local Domestic Violence Forum. Manchester's Bradford CAB, together with the Greater Manchester Probation Service, was involved in research into the problems faced by parents of young offenders.

\section{Publicity, promotion and outreach work}

Amongst the library authorities, promotion of the community information service is largely restricted to basic publicity leaflets or posters displayed within their libraries. However, a number have held special exhibitions and displays on particular themes (e.g. adult education, health care information, drugs awareness) and have produced press releases and other promotional material for these events.

In the $\mathrm{CABx}$ and other agencies, promotional leaflets and posters in public buildings are also to the fore, and many give talks to groups such as community groups, tenants' associations 
and Women's Institutes. A small number have embarked on more sophisticated methods: Belfast and Manchester $\mathrm{CABx}$ have regular advice columns in local newspapers, and Manchester $\mathrm{CAB}$ also has a regular monthly slot on local radio. Brighton and Peterborough $\mathrm{CABx}$, and the West Somerset Bureau also use local newspapers and radio, although on an ad hoc basis and generally in response to important topical issues. The Turnpike Lane Advice Bureau, along with the other Haringey Council bureaux at Hornsey and Tottenham, provides an advice column in the Council's online newsletter Haringey People.

It is fair to say, though, that publicity for the $\mathrm{CABx}$ and the other agencies is regarded as something of a double-edged sword, for it can create a demand that these organisations might not be able to meet. As a result, many are wary about conducting large-scale publicity campaigns, and prefer to concentrate their promotional work on attracting new volunteer advisers. This is a perennial problem for under-resourced services - and also a paradox of the need to demonstrate demand for, and value of, services.

\section{Links with other organisations and information providers}

Each one of the case study organisations has developed links and contacts with other citizenship information providers and with those groups and organisations (e.g. voluntary, charitable and representative groups) with a major interest in citizenship information needs and provision. At the most basic level, these links and contacts are generally for referral purposes and can be with, for example, local offices of central government departments and agencies, local offices or representatives of national voluntary organisations (e.g. Age Concern and Shelter), local council departments, and organisations dealing specifically with local needs (e.g. Brighton Housing Trust and Somerset Welfare Rights Unit).

A number of the organisations, particularly the $\mathrm{CABx}$ and other advice agencies, are members of more formal networks which meet regularly to discuss and develop local citizenship information and advice provision. These networks can cover citizenship information and advice in general; for example, the Manchester CABx Service is a member of the Manchester Advice Network. Or they can be devoted to particular subject areas: for example, Aberdeen CAB is part of the local Welfare Benefits Take-up Campaign, an offshoot of the Aberdeen Committee for the Elderly designed to increase benefits take-up amongst older people. 
Several of the case studies have established practical service initiatives in partnership with other organisations, and a number of these have already been outlined above. Seven of the library authorities host $\mathrm{CABx}$ sessions in one or more of their branch libraries on particular days of the week. Liverpool's community libraries have hosted drop-in sessions held by the local Adult Guidance Unit, the Benefits Agency and the Inland Revenue; Sheffield's Upperthorpe Library plays host to the Langsett Centre's Community Rights advice service; and Birmingham Central Library permanently hosts a National Youth Agency Information Shop for Young People. As well as in libraries, many of the case study CABx and other advice agencies hold regular advice sessions in locations such as community centres, hospitals and doctors' surgeries; and, in the case of Manchester CAB, Strangeways Prison and the Manchester Magistrates' Court.

\section{Future developments}

Respondents were asked if there were any plans to change or develop their citizenship information service in the future. In the public libraries, future developments revolve almost entirely around the use of ICTs: systems are to be introduced, expanded or improved, allowing more potential for electronic citizenship information provision; current stand-alone sources are to be networked, allowing wider public access; Internet access, both for staff and the public, is to be expanded; and most of the authorities currently without a community information database plan to develop one. The public library interviews were conducted prior to the publication of the Library and Information Commission's public library networking plan (LIC, 1997). It is perhaps safe to assume that the opportunities presented by the proposed 'People's Network' will now also be prominent in these authorities' plans.

For many of the CABx and other agencies, financial restraints mean that the focus is on consolidation and the maintenance of their service at current levels, rather than on expansion and development. As a result, these organisations acknowledge that many of their plans are unlikely to reach fruition, at least in the immediate future.

For two of the CABx and two of the advice agencies, upgrading or extending their accommodation, or finding new premises, is a priority. Indeed, it is fair to say that these particular organisations, and a number of the others visited, are located in rather cramped premises that are not particularly accessible to infirm or disabled people. Staff and staff training is also an important consideration. Virtually all of the organisations would like to attract and retain more volunteer advisers; indeed, the Orrell Park Centre is planning to make 
a bid for funding from the Opportunities for Volunteers fund, to employ a volunteer coordinator to attract and train volunteer advisers. The Byker Project, meanwhile, hopes to offer National Vocational qualifications in advice work to its advisers. Brighton CAB and the West Somerset Bureau are to apply for Legal Aid Board non-solicitor franchises to provide legal advice and assistance.

Aberdeen $\mathrm{CAB}$ would like to undertake more 'preventative' outreach work, perhaps in schools, that might prevent people, say, running into debt in later life. Manchester CABx plan to carry out more outreach work with ethnic minority groups. Both Belfast and Manchester $\mathrm{CABx}$ would like to introduce telephone helplines, constantly manned by several volunteer advisers, to deal more efficiently with telephone enquiries.

\section{Conclusions}

Public libraries, $\mathrm{CABx}$ and other advice agencies from all 13 regions of the UK were visited to gather data on service provision and issues of concern to providers. In total, 27 organisations were visited. Specialised local needs identified included: greater need for HIV/AIDS information; financial problems and debts; seasonal unemployment; and, in Belfast, dealing with the effects of bombing or intimidation. Problems identified included: users from other catchment areas utilising the service; and users' requirement for privacy/confidentiality in their approach to the agency, particularly in close-knit communities

From the findings, public libraries (with one exception) concentrate on the facilitation of access to factual information, while $\mathrm{CABx}$ and other agencies provide information and advice. $\mathrm{CABx}$ and other agencies will also provide representation for clients at tribunals and court appearances. There is limited availability of home visits to housebound users in public libraries, while most $\mathrm{CABx}$ and other agencies will provide this service (even if they do not advertise the fact widely).

$\mathrm{CABx}$ and other agencies utilise a mix of paid full-time and part-time and unpaid volunteer staff. This reliance on volunteers creates problems. Public library services (with one exception) tend not to dedicate staff to community/citizenship information service. Public libraries might benefit from considering the volunteer approach.

All CABx staff and volunteers complete a basic training programme and have available a supplementary and more specialist set of training programmes. It is planned to develop this 
suite of training into an externally accredited qualification. Other agencies adopt a range of approaches built upon in-house training. Public libraries tend not to have developed such an in-depth approach. Staff will receive some induction and training, but only as part of more generic training. The Sheffield exemplar of participating freely in other agencies' training on a quid pro quo basis might be drawn upon by other services.

The provision of staff with minority and sign language skills tends to be reactive to demand from, and perceived need in, their respective user communities.

There was poor availability of statistical information in public library services. Conversely, $\mathrm{CABx}$ had a systematic approach which enabled analysis of enquiries into subject categories. For $\mathrm{CABx}$ and other information agencies, welfare benefits and consumer/debt were the most prominent topics dealt with.

Users tended to approach all services primarily by a personal visit, followed in frequency by a telephone call. Telephone approach was more common in CABx and other agencies than in public libraries. There was a feeling amongst staff of $\mathrm{CABx}$ and other agencies that the telephone approach would become more common. Staff felt that users preferred face-to-face contact, but that a telephone approach was useful where privacy/confidentiality was desirable. Staff also felt that users received a better and more tailored response when a personal visit was made. The significance of the reference interview is supported by these findings.

Only four of the case study organisations had conducted recent surveys of user needs including user surveys and analyses of enquiries received. Additionally, all CABx analyse evidence forms to identify significant issues and problems amongst clients. This is a particularly proactive function that might be employed to effect in public libraries and other agencies.

Similarly, studies of user satisfaction are rare: only two libraries and none of the other information agencies had carried out surveys or engaged in user forums. On the other hand, NACAB requires that such a study be carried out every three years by all CABx.

The CABx network has developed the NACAB Information System, a monthly updated set of 12,000 pages of information, which is supplemented by a range of useful publications. Some of the other information agencies also subscribe to the NACAB system, but otherwise 
collections were variable in scope and size. Public libraries were split between those that had collated their community/citizenship collections into a discrete section, and those whose materials were dispersed throughout their classified sequence. While some services had collections which included monographs, a significant number relied almost completely on pamphlet literature. Only two libraries held the full version of the NACAB Information System. Some also subscribed to Camden Information Service's Free Leaflet Information System (FLIS). Individual library services had developed special collections on, for example, drugs awareness, HIV/AIDS, and, in four cases, local council information points. Some of the case study organisations were producing their own citizenship information materials, including directories of relevant services, self-help information packs and pamphlets.

The majority of $\mathrm{CABx}$ do not presently access or enable public access to information electronically, although two are developing systems for database access and e-mail enquiry. A remotely accessible electronic version of the NACAB Information System is also being piloted. It is hoped that a bid for funding to support the development of CABnet, linking all bureaux, will in the future prove successful. Similarly, in the other information agencies, apart from isolated projects, there is little evidence of the application of ICTs.

Public libraries tend to have produced local community/citizenship information databases. Only seven of the authorities visited provided public access to the Internet, but others were planning the introduction of such a service. Again, certain authorities had more highly developed projects underway, such as the Manchester MAGIC TOUCH kiosks and the Cambridge Online City website. Two services were utilising videotelephony to enable access to an adviser.

In libraries, promotion largely takes the form of leaflets, posters and special displays. CABx also utilise leaflets and posters. Staff also give talks, produce columns for local newspapers or host radio slots. There is the usual concern for all under-funded resources that promotion may simply create a demand that cannot be met.

Links between services tend to be developed for referral purposes. CABx are part, of course, of a formal network with a programme of support. Partnerships were also in evidence, as for example with the seven library authorities that host $\mathrm{CABx}$ in branches on a periodical basis. 
In public libraries, future developments significantly revolved around ICTs. For CABx the focus tended to be on consolidation and maintenance of the quality of service, or in developing 'preventative' approaches to clients' problems.

It has become clear in the course of conducting this research that public libraries can learn from the $\mathrm{CABx}$ and vice versa. The fact that $\mathrm{CABx}$ and other information agencies frequently have a very focused set of aims and objectives means that they have in some instances developed policies and operational approaches that are particularly effective in providing a reliable and responsive service for their client group. In particular in terms of being aware of the need for privacy/confidentiality, and in the need for extending service beyond enabling access to acting as a form of expert and informed support, in interpreting, contextualising, and advising users. The concept of expert staff might be strengthened by the provision of dedicated staff and seeking to find ways of allowing greater participation in cooperative training ventures. Public libraries have two potentially great advantages in providing a service: the developed network of public library services with enhanced access to remote collections; and a presence and reputation in the community that is not directly related to any specific, and possibly embarrassing for the user, function. It is felt that public libraries could develop a more proactive approach to the identification of issues where information is being or will be required by users.

As ever, there is the concern that promoting the service will simply create a demand that cannot be met in a situation where resources are constantly being reduced. This is, of course, a thorny issue and one for which there is no simple solution. It is not limited to libraries but is encountered in all publicly funded sectors. There are questions of the philosophy of service, but also, more importantly, of developing strategies to demonstrate impact and value in terms that can be understood by funding bodies and where there is demonstrable advantage to supporting the public library service as a resource. In this area of citizenship information provision, the researchers believe that there are such demonstrable advantages in ensuring a well-informed population that can take advantage of educational, vocational, health-related, social and government resources to improve their lives and reduce dependence on alternative forms of government support.

A number of recommendations for information service provision have been developed from the results of the project: 
1) that public library services should re-examine their philosophy of information service in terms of the long running 'information vs. advice' debate, in considering their role alongside the other information and advice agencies;

2) that the $\mathrm{CABx}$ service has effectively overcome staffing deficiencies by developing specialist training programmes: collaborative approaches to training between public libraries, $\mathrm{CABx}$ and other agencies would aid the exploitation of limited resources and expertise;

3) that more frequent and more revealing statistics should be gathered on user needs and preferred patterns of information seeking: such data would assist strategic planning of services and provide a framework within which services might comparatively evaluate their own performance;

4) that the LIS sector should initiate and contribute to the debate upon the subject retrieval of citizenship/community information: a research project focusing upon search strategies (in print and electronic media) and subject indexing approaches would aid in the development of systems that aid relevant and precise retrieval;

5) that further basic research into the impact of ICTs on information is necessary, in particular examining potential barriers to access;

6) that a greater degree of collaboration and cooperation between all of the agencies operational in this field is desirable, in that this would increase holistically our understanding of the most effective forms of service provision, improve outreach into communities and ensure that scarce resources are exploited to their maximum advantage;

7) and that in order to have a greater impact on the communities they serve and on those that have input to the policy making process, a more coordinated approach to service provision is necessary both within and across service sectors. 


\section{References and Bibliography}

Beer, Susan F., Marcella, Rita, and Baxter, Graeme (1998) Rural citizens' information needs: a survey undertaken on behalf of the Shetland Islands Citizens Advice Bureau. Journal of Librarianship and Information Science, 30(4), pp.223-240.

Bunch, Allan (1988) Community information. In: Bromley, David W., and Allott, Angela M., eds. British librarianship and information work, 1981-1985, volume 1. London: Library Association, pp.186-202.

Cambridge Online City (1997) Home page.

Available at http://www.worldserver.pipex.com/cambridge/index.html [Accessed May 1999]

Cambridgeshire Education, Libraries \& Heritage (1997) Infocam: community information database. Available at http://www.camcnty.gov.uk/infosearch.html [Accessed May 1999]

Camden Information Services (1997). Free Leaflet Information Service (FLIS). Information leaflet and list of subscribers.

Charnwood Online (1998) Home page. Available at: http://www.charnwood-online.org.uk/ [Accessed May 1999]

Chartered Institute of Public Finance and Accountancy (1998) Public library statistics 199697 actuals. London: CIPFA.

Citizens Advice Scotland (1996a) Directory of information. Edinburgh: CAS.

Citizens Advice Scotland (1996b) A Scottish voice: annual report 1995/1996. Edinburgh: CAS.

Computanews (1997) The future - and it works. Computanews, no.92. Available at http://www.pcug.co.uk/ lasa/niacab.htm [Accessed May 1999]

Computanews (1998) Scots CABx withdraw information system. Computanews, no.93. Available at http://www.pcug.co.uk/ lasa/casfp.htm [Accessed May 1999] 
Donohue, Joseph C. (1976) Community information services - a proposed definition. In: Martin, S.K., ed. Community information politics. Proceedings 39th ASIS annual meeting. Vol. 13. Washington: American Society for Information Science.

Electronic Immigration Network (1998) Home page. Available at http://www.ein.org.uk/ [Accessed May 1999]

Haringey Council (1998) Haringey people.

Available at http://www.haringey.gov.uk/data/peoplweb/ [Accessed May 1999]

Langsett Advice and Area Resource Centre (undated) Home page. Available at http://www.shef.ac.uk/ oip/laarc/ [Accessed May 1999]

Library Association (1980) Community information: what libraries can do. London: Library Association

Library Association (1993) A charter for public libraries. London: LA.

Library Association (1996) Libraries in the United Kingdom and the Republic of Ireland 1997. London: Library Association.

Library and Information Commission (1997) New library: the people's network. Available at http://www.ukoln.ac.uk/services/lic/newlibrary/full.html [Accessed May 1999]

Liverpool Libraries \& Information Services (1997) Multiracial Library Promotions Unit web page. Available at: http://www.liverpool.gov.uk/public/council_info/direct-info/leisure/ libraries/mrlpu.htm [Accessed August 1997; site temporarily withdrawn at January 1999]

Manchester Citizens Advice Bureaux Service (1995) Home page. Available at http://www.poptel.org.uk/cab/ [Accessed May 1999]

Manchester Community Information Network (1996) Home page. Available at http://www.mcin.net/ [Accessed May 1999] 
Manchester City Council Department of Libraries and Theatres (1999). INFORM - the database of local groups and societies.

Available at http://manchester.gov.uk/mccdlt/inform.html [Accessed May 1999]

Marcella, Rita, and Baxter, Graeme (1999) The information needs and the information seeking behaviour of a national sample of the population in the United Kingdom, with special reference to needs related to citizenship. Journal of Documentation, 55(2), pp.159-183.

Moore, Nick, and Steele, Jane (1991) Information-intensive Britain. British Library Research and Development Department Report No. 6038. London: Policy Studies Institute.

National Association of Citizens Advice Bureaux (1996a) CAB service directory. London: NACAB.

National Association of Citizens Advice Bureaux (1996b) Delivering human rights: annual report 1995/96. London: NACAB.

National Association of Citizens Advice Bureaux (1997) Connecting society: annual report 1996/97. London: NACAB.

Available at: http://www.nacab.org.uk/annualreport/report_25_1.html [Accessed May 1999]

Ward, John, and Mason, Sara (1986) The development of advice and information services in the United Kingdom. Information and Referral, 8(1), pp.1-14. 